\title{
Removal of Agricultural Non-Point Source Pollutants by Artificial Aquatic Food Web System: A Study Case of the Control of Cynobacterial Bloom in Jiyu River
}

\author{
Nichun Guo', John A. Dowing ${ }^{2}$, Christopher T. Filstrup ${ }^{2}$, Deqin Yu${ }^{1}$, Wenhao Ji ${ }^{1}$, Youhua Ma1 \\ ${ }^{1}$ Resources and Environment College, Anhui Agricultural University, Hefei, China \\ ${ }^{2}$ Ecology, Evolution, and Organismal Biology Department, Iowa State University, Ames, USA \\ Email: guonichun@ahau.edu.cn
}

How to cite this paper: Guo, N.C., Dowing, J.A., Filstrup, C.T., Yu, D.Q., Ji, W.H. and Ma, Y.H. (2016) Removal of Agricultural Non-Point Source Pollutants by Artificial Aquatic Food Web System: A Study Case of the Control of Cynobacterial Bloom in Jiyu River. Open Journal of Ecology, 6, 699-713.

http://dx.doi.org/10.4236/oje.2016.612064

Received: October 1, 2016

Accepted: November 8, 2016

Published: November 11, 2016

Copyright $\odot 2016$ by authors and Scientific Research Publishing Inc. This work is licensed under the Creative Commons Attribution International License (CC BY 4.0).

http://creativecommons.org/licenses/by/4.0/

(c) (i) Open Access

\begin{abstract}
An artificial aquatic food web (AAFW) system was designed to remove the nonpoint source pollutants in eutrophic Jiyu river. A certain amount of Scenedesmus obliquus and Daphnia pulex was cultured in the system for the control of serious cyanobacterial bloom. The AAFW system was a continuous-flow system including one storage basin of $3 \mathrm{~m}^{3}$ capacity with polluted river water (the total nitrogen-TN: 4.49 $\mathrm{mg} \cdot \mathrm{l}^{-1}$; the total phosphorus-TP: $0.192 \mathrm{mg} \cdot \mathrm{l}^{-1}$ ), one phytoplankton tank of $3 \mathrm{~m}^{3} \mathrm{ca}-$ pacity with an initial concentrations of $S$. obliquus about $5.8 \times 10^{3}$ ind. $1^{-1}$, and one zooplankton growth chamber of $1.5 \mathrm{~m}^{3}$ capacity with an initial abundance of $D . p u$ lex about 22.5 ind $\cdot l^{-1}$. The system was optimized by setting hydraulic retention time of phytoplankton tank as 5 days and the experiments were operated for 45 days. Compared with the polluted river, TN and TP were removed about $28 \%$ and $47 \%$ by the AAFW system, respectively. The biomass of phytoplankton decrease from 6.33 $\mathrm{mg} \cdot \mathrm{l}^{-1}$ to $1.48 \mathrm{mg} \cdot \mathrm{l}^{-1}$ and the percentage of cyanobacteria decrease from $43.93 \%$ to $2.36 \%$, the biomass of Crustacean zooplankton increase from $0.34 \mathrm{mg} \cdot \mathrm{l}^{-1}$ to $1.53 \mathrm{mg} \cdot \mathrm{l}^{-1}$ and the percentage of $D$. pulex increase from $19.19 \%$ to $57.62 \%$. Our results indicated that the AAFW system not only is an efficient, flexible system for reducing nutrient levels in tributary rivers, but also has an ability to control the cyanobacteria bloom and rebuilding the aquatic ecosystem from the polluted river water.
\end{abstract}

\section{Keywords}

Non-Point Source Pollutants, Artificial Aquatic Food Web System, Reducing Nutrient Levels, Cyanobacterial Bloom Control 


\section{Introduction}

Non-point source pollution from the industry agriculture has been becoming the major reason for eutrophication of rivers and lakes [1]. Excessive chemical fertilizer application in the industry agriculture led to increases of nitrogen $(\mathrm{N})$ and phosphorus $(\mathrm{P})$ in the drainage [2] [3], which result in a rapid growth of algae in freshwater and led to some damages to the aquatic ecosystems [4] [5]. As an important inflow path to eutrophic Chaohu lake, the pollution sources of Jiyu river were mainly from agricultural non-point pollution, which were not treated effectively [6]. The eutrophication of Jiyu river has been characterized as the main reason for the water deterioration and the serious cyanobacterial bloom [7]. Many studies suggested the control of eutrophication attribute to the management of nutrients, especially external nutrients from the nonpoint pollution by industry agriculture [8] [9]. While it is difficult to reduce the biomass of cyanobacteria by the removal of the non-point source pollution solely, not only attribute to high concentrations of pollutants, but also because its pollutants are coming from many diffuse sources at relatively low concentrations [10] [11] [12]. A high biomass of zooplankton may result in a control of phytoplankton [13], while the dominance of large filamentous and colonial cyanobacteria in the phytoplankton community inhibit the cascading effects of natural biomass levels of both visually feeding zooplanktivores and filter-feeding omnivores [14] [15]. So recently researches found that cyanobacteria usually blooms when the ratio of TN:TP is low, and a high abundance of zooplankton (mainly composed by small cladocerans and rotifers) fail to control the cyanobacterial blooms [13] [16]. The dynamic of TN: TP and the grazing of large-bodied zooplankton were important to the control of cyanobacterial bloom [1] [17]. A change of trophic cascade and a rebuilding of aquatic ecosystem in the polluted river water were needed for the control of cyanobacterial bloom [9] [18] [19].

Many ecotechnologies, such as constructed wetland [2], artificial floating islands [20], and floating mats [21], were designed to remove non-point source pollutants of rivers and lakes, while it's unknown to change the ratio of TN:TP and the trophic cascade of aquatic ecosystem. An artificial aquatic food web (AAFW) system composed by three trophic levels was designed not only for the removal of nutrients from the non-point source of Chaohu basin, but also reflect the trophic cascade when many biotic and abiotic factors were mixing [4] [9]. The design is a revision of the AAFW system developed by Jung et al. (2009) [9], which is proven to remove nutrients effectively from sewages containing high concentrations of nutrients. Otherwise, the addition of $S$. obliquus and D. pulex in the AAFW system would reflect the change of the nutrientphytoplankton-zooplankton interactions from the polluted river water. The design of the continuous-flow AAFW system was divided into three parts: The first part was transformed the dissolved nutrients in polluted river water into biomass of phytoplankton, and the second part was transferred into $D$. pulex by grazing; finally, the harvesting of Daphnia would removed the nutrients and the harmful phytoplankton. In this study, the hydraulic retention time (HRT) of phytoplankton and Daphnia was evaluated by the growth parameters of phytoplanktonic organisms and D. pulex under 
different conditions. The AAFW system was operated for 45 days, and steady and efficient removal of nutrients and harmful cyanobacteria from river water was confirmed.

\section{Materials and Methods}

\subsection{Characteristics of Target River}

The target river (Jiyu river) used for the construction of the AAFW system for the removal experiments of nutrient and harmful cyanobacteria was located in Tongyang, Hefei, China $\left(31^{\circ} 39^{\prime} 59^{\prime \prime} \mathrm{N}, 117^{\circ} 40^{\prime} 48^{\prime \prime} \mathrm{E}\right)$. This area has a subtropical climate, with an annual mean air temperature of $16.1^{\circ} \mathrm{C}$, an annual rainfall from $1000 \mathrm{~mm}-1158 \mathrm{~mm}$, and an annual potential evaporation of $1124.4 \mathrm{~mm}$. The river is known to receive farm wastes and septic tank pollutions, and 2 samples were collected in the polluted river (Figure 1). Total nitrogen (TN), nitrate $\left(\mathrm{NO}_{3}^{-}\right)$, total phosphorus (TP), dissolved inorganic phosphorus(DIP) concentrations and the cyanobacterial biomass in the river water during the period of experiments (May 14-July 2, 2015) were $4.49 \pm 0.45$ (mean \pm $\mathrm{SD}), 0.99 \pm 0.22,0.19 \pm 0.04,0.07 \pm 0.1$ and $2.21 \mathrm{mg} \cdot \mathrm{l}^{-1}$ respectively. The ratio of nitrate to TN ranged from $2.86 \%$ to $47.25 \%$, the ratio of DIP to TP from $3.92 \%$ to $87.50 \%$, the ratio of TN: TP from 11.70 to 45.23 , the percentage of Daphnia in zooplankton community from $6.08 \%$ to $19.44 \%$ and the percentage of cyanobacteria in phytoplankton community from $12.17 \%$ to $69.14 \%$ (Table 1 ).

\subsection{Facilities for AAFW System}

The artificial food web system was designed by adopting the basic aspects of a laboratory-scale AAFW system that was developed by Jung et al. (2009) [9], which consisted

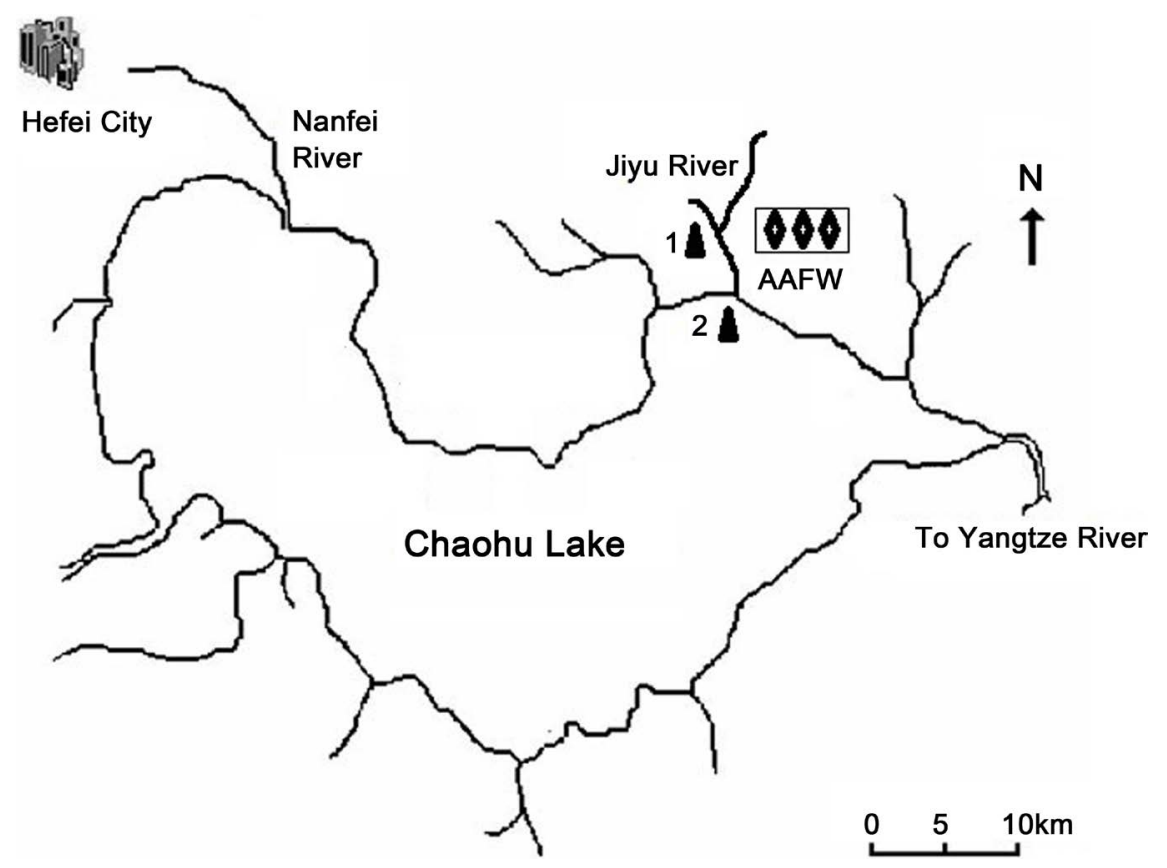

Figure 1. Map of the Chaohu basin showing the location of AAFW and the sample sites in the Jiyu river. 
Table 1. Mean and range of water quality variables observed in the target stream during operation of the artificial aquatic food web system.

\begin{tabular}{cccc}
\hline Item & Minimum & Maximum & Mean \\
\hline $\mathrm{Temp}\left({ }^{\circ} \mathrm{C}\right)$ & 23.90 & 28.40 & 25.94 \\
$\mathrm{pH}$ & 7.41 & 9.19 & 7.88 \\
$\mathrm{DO}\left(\mathrm{mg} \cdot \mathrm{l}^{-1}\right)$ & 4.6 & 17.9 & 9.36 \\
$\mathrm{TN}\left(\mathrm{mg} \cdot \mathrm{l}^{-1}\right)$ & 3.04 & 9.05 & 4.49 \\
$\mathrm{NO}_{3}^{-}\left(\mathrm{mg} \cdot \mathrm{l}^{-1}\right)$ & 0.15 & 1.87 & 0.99 \\
$\mathrm{NO}_{3}^{-} / \mathrm{TN}(\%)$ & 2.86 & 47.25 & 22.01 \\
$\mathrm{TP}\left(\mathrm{mg} \cdot \mathrm{l}^{-1}\right)$ & 0.0300 & 0.4200 & 0.1921 \\
$\mathrm{DIP}\left(\mathrm{mg} \cdot \mathrm{l}^{-1}\right)$ & 0.0125 & 0.2650 & 0.0772 \\
$\mathrm{DIP} / \mathrm{TP}(\%)$ & 3.92 & 87.50 & 40.21 \\
$\mathrm{TN} / \mathrm{TP}$ & 10.63 & 57.54 & 23.36 \\
$\mathrm{~PB}^{*}\left(\mathrm{mg} \cdot \mathrm{l}^{-1}\right)$ & 2.28 & 17.87 & 6.33 \\
$\mathrm{CB}\left(\mathrm{mg} \cdot \mathrm{l}^{-1}\right)$ & 0.83 & 3.89 & 2.21 \\
$\mathrm{CA} / \mathrm{PA}(\%)$ & 12.17 & 69.24 & 37.89 \\
\hline
\end{tabular}

DO: the concentration of dissolved oxygen, TN: total nitrogen, $\mathrm{NO}_{3}^{-}$: nitrate, TP: total phosphorus, DIP: dissolved inorganic phosphorus, PB: Phytoplankton Biomass, CB: Cyanobacteria Biomass.

by one storage basin (ca $3 \mathrm{~m}^{3}, \varnothing=1.48 \mathrm{~m}, \mathrm{~d}=1.7 \mathrm{~m}$ ), one phytoplankton tank (ca $3 \mathrm{~m}^{3}$, $\varnothing=2.6 \mathrm{~m}, \mathrm{~d}=0.75 \mathrm{~m})$, and one zooplankton growth chamber $\left(\mathrm{ca} 1.5 \mathrm{~m}^{3}\right.$ capacity $(\mathrm{w}=$ $1.2 \mathrm{~m} \times 2.4 \mathrm{~m}, \mathrm{~d}=0.6 \mathrm{~m}$ ), arranged sequentially in downward steps (Figure 2). River water was supplied by a drain pump at the velocity of $100 \mathrm{l}$ per min. The major function of the storage basin was to dampen fluctuations in quality and quantity of the input water. The floor of the phytoplankton tank had a $10^{\circ}$ slope toward the center of the tank bottom for the collection of sludge, and 51 of sludge at the bottom of the tank was drained out on every 5 days. Otherwise, water in the phytoplankton tank was circulated at the velocity of $100 \mathrm{l} \cdot \mathrm{min}^{-1}$ by a water pump for the optimum growth of phytoplankton during the day time. For the collection of sludge, the floor of the zooplankton chamber had a $10^{\circ}$ vertical slope from the inlet to outlet. Water temperature of the zooplankton chamber was kept as $25.0^{\circ} \mathrm{C} \pm 3.5^{\circ} \mathrm{C}$ (mean $\pm \mathrm{SD}$ ) with an aquarium heater. A shade was placed on the top side of the chamber, to avoid irradiation by direct sunlight. About 51 of sludge at the bottom of the chamber was drained out on every 5 days. The effluent was filtered through the sand and gravel layers to prevent the loss of individuals of $D$. pulex population.

\subsection{Continuous-Flow AAFW System}

The continuous-flow AAFW system was operated with the target river water for 45 days after the establishment of the phytoplankton community and acclimation of the $D$. pulex population for 15 days. During the period of operation, water temperature was $25.0^{\circ} \mathrm{C} \pm 3.5^{\circ} \mathrm{C}$ in the phytoplankton tank and the zooplankton chamber. The HRT of 


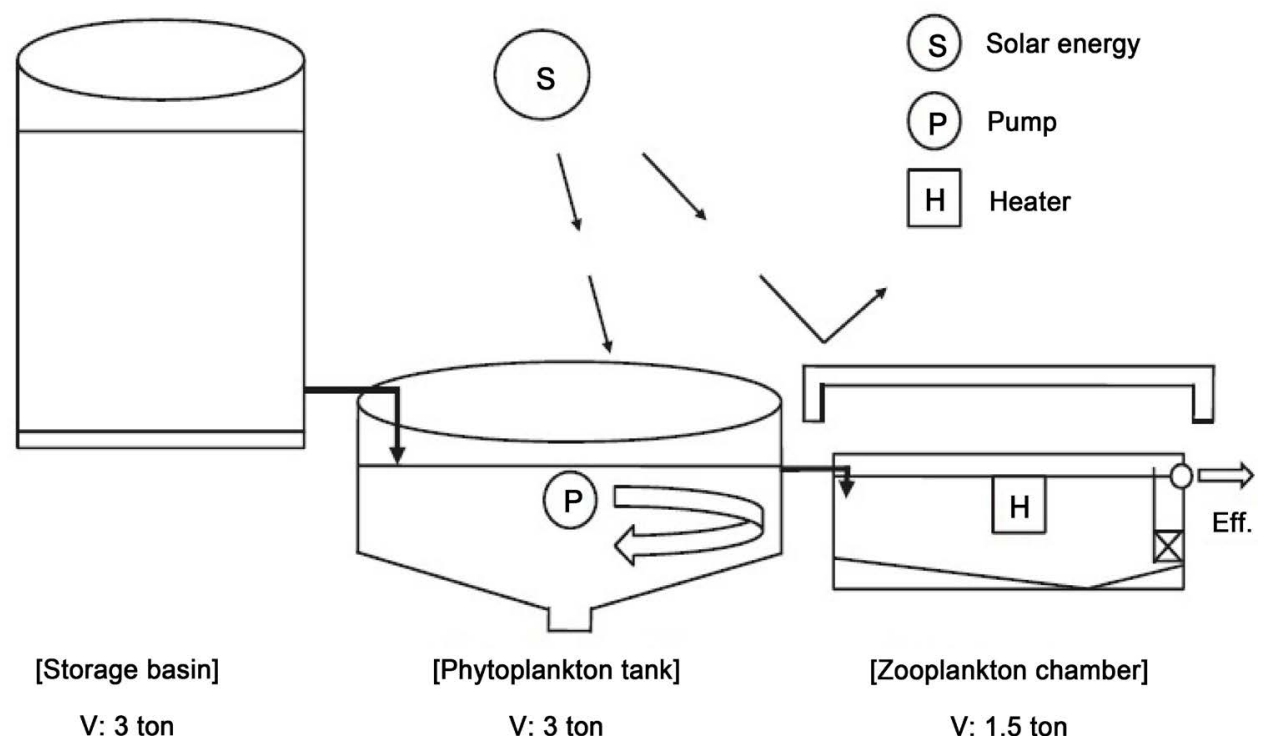

Figure 2. Schematic diagram of artificial aquatic food web system.

the phytoplankton tank was set to 5.0 days. The initial concentration of $S$. obliquus in the phytoplankton tank was about $5.8 \times 10^{3}$ ind. $1^{-1}$ and the initial density of $D$. pulex in the zooplankton chamber was about 22.5 individual. $1^{-1}$. In order to determine the efficacy of the AAFW system in removing the nutrients from river water, water samples were taken from the storage basin, the phytoplankton tank, the zooplankton chamber, and the effluent at 14:00 of a day at 5-day intervals, and analyzed for TN, nitrate, TP and DIP concentrations by the standard methods [22]. Dissolved oxygen and $\mathrm{pH}$ were determined with an Orion 810 dissolved oxygen meter and an Orion $210 \mathrm{pH}$ meter. Phytoplankton samples were preserved with $1 \%$ acidified Lugol's iodine solution and concentrated to $30 \mathrm{ml}$ after sedimentation for $48 \mathrm{~h}$. After mixing, $0.1 \mathrm{ml}$ concentrated samples were counted and measured under $\times 400$ magnification. To count Microcystis cells, the samples were agitated by gentle ultrasonication to split the colonies into single cells. Phytoplankton species were identified to species level by the method of $\mathrm{Hu}$ et al. (1979) [23]. Crustacean zooplankton was examined under $\times 40$ magnification. Biomass (wet weight) of crustacean zooplankton was estimated using the length-weight regressions according to Zhang and Huang (1991) [24]. Measurements were taken in triplicate for all water quality variables. Based on these results, the HRT in the phytoplankton tank was set to 5 days.

\section{Results and Discussion}

\subsection{The Removal of Nutrients by the AAFW System}

In the present study, the AAFW system removed nutrients from polluted river water, which was a resource of the non-point source pollution from industry agriculture. The concentrations of TN and $\mathrm{NO}_{3}^{-}$in the storage basin averaged 4.46 and $0.69 \mathrm{mg} \cdot \mathrm{l}^{-1}$, respectively, where as those in the effluent of the continuous-flow system were 3.17 and $0.18 \mathrm{mg} \cdot \mathrm{l}^{-1}$, respectively. The concentrations of TP and DIP in the storage basin were 
0.23 and $0.058 \mathrm{mg} \cdot \mathrm{l}^{-1}$, respectively, and decreased to 0.12 and $0.053 \mathrm{mg} \cdot \mathrm{l}^{-1}$ in the effluent, respectively (Figure 3 ). Based on these mean values, the mean removal efficiencies of TN, $\mathrm{NO}_{3}^{-}$, TP and DIP were calculated to be $28,73,47$, and $17 \%$, respectively. These removal efficiencies were lower than those of previous studies using artificial food web systems [9] [12] [25] or other industrialized techniques [26] [27]. These results may attribute to the lower concentrations of nutrients in the target river water and pollutants are coming from many diffuse sources. The ratio of TN:TP in the effluent of the continuous-flow system is 36.40 , while the ratio of TN:TP in the Jiyu river is 26.19 . So, the ratio of TN:TP in polluted river water increase $38.97 \%$ after it was treated with the AAFW system (Figure 4). The significant increase of TN:TP in the zooplankton chamber may attribute to the phosphorus $(\mathrm{P})$ absorption of lager claoderans-Daphnia pulex. It was reported Daphnia which have low body N:P dominated zooplankton communities when seston N:P were also low [16]. Brett et al. (2000) found that Diaptomus markedly increased SRP relative to DIN, resulting in a low DIN: SRP ratio [28]. In contrast, Daphnia increased the DIN: SRP ratio. Similar patterns were evident in the present study. The mean $\mathrm{pH}$ and $\mathrm{DO}$ of the target river was $7.88 \pm 0.43$ and $9.36 \pm 2.24$
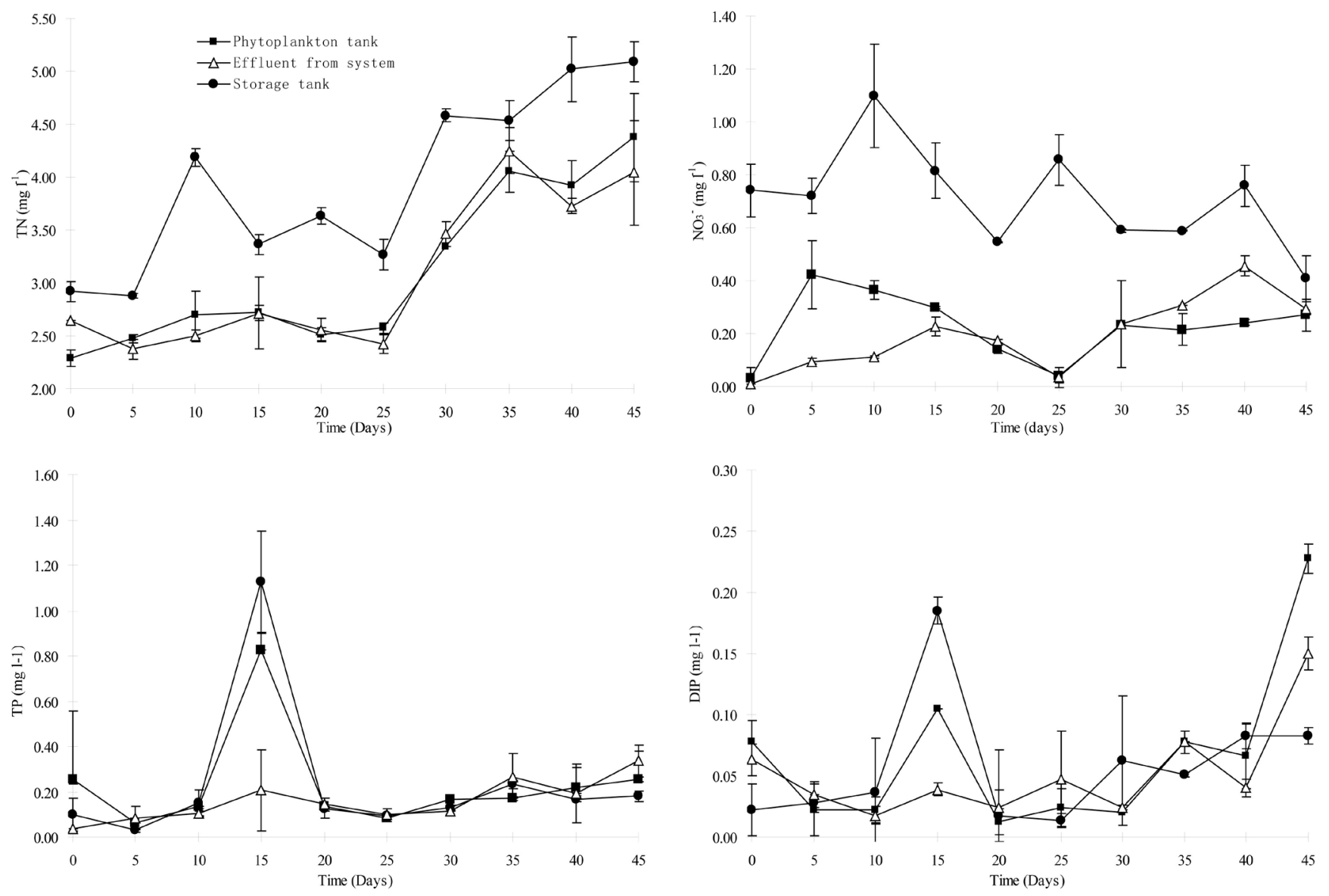

Figure 3. Variations of total nitrogen (TN), nitrate $\left(\mathrm{NO}_{3}^{-}\right)$and total phosphorus (TP) and dissolved inorganic phosphorus (DIP) during operation of the continuous-flow AAFW system. Black circle storage tank, black square phytoplankton tank, and inverted triangle effluent from system. 

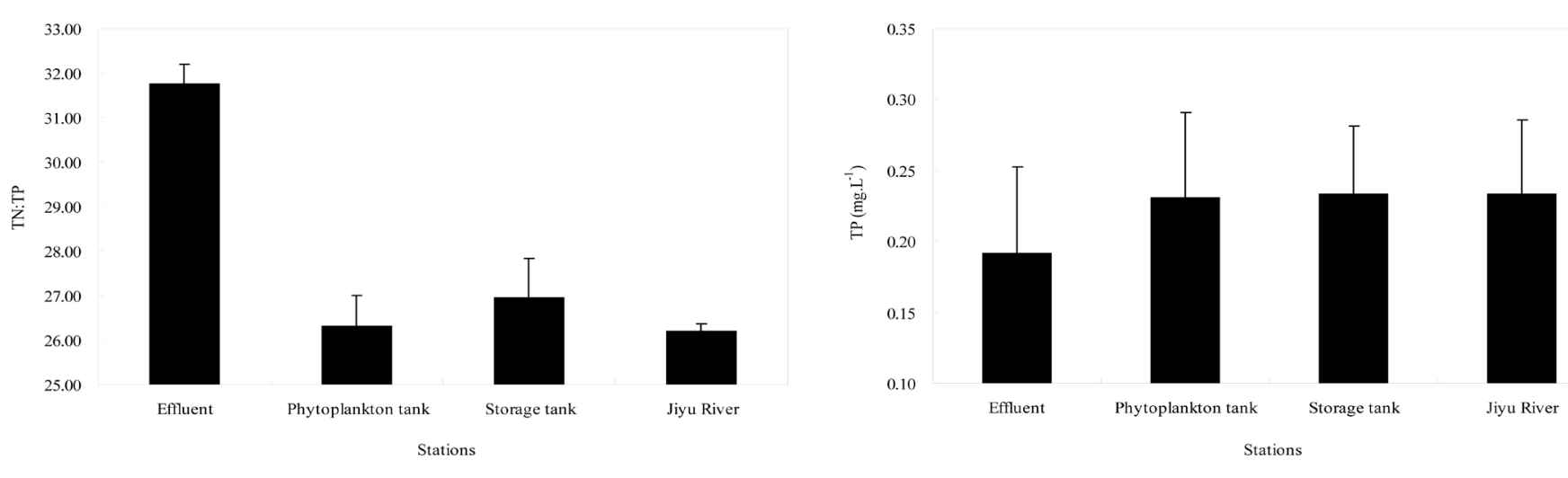

Figure 4. The ratios of TN:TP (left) and the concentrations of TP (right) in different sample sites.

$\mathrm{mg} \cdot \mathrm{l}^{-1}$ respectively. While $\mathrm{pH}$ and $\mathrm{DO}$ values in the phytoplankton tank $(9.28 \pm 0.50$ $\left.9.96 \pm 2.40 \mathrm{mg} \cdot \mathrm{l}^{-1}\right)$ were higher than the zooplankton chamber $(9.10 \pm 0.38,8.23 \pm 1.37$ $\mathrm{mg} \cdot \mathrm{l}^{-1}$ ). The marked decrease in the $\mathrm{pH}$ value from the target river to the AAFW system indicated negligible nutrients- phytoplankton-zooplankton interaction in the AAFW system (Table 1).

\subsection{The Change of Plankton Community in the AAFW Systems}

\subsubsection{The Change of Phytoplankton Community}

Eutrophication is known to change the phytoplankton community. The most obvious changes have been seen in the phytoplankton community where a transition from small, edible algae to larger and less edible diatoms, chlorophytes and filamentous, toxic and PUFA-deficient Cyanobacteria. In the present study, 83 phytoplankton taxa identified. Green algae (31 taxa), cyanobacteria (19) and diatoms (13) were richest in taxa. Compared with the phytoplankton community in Jiyu river, the abundance and biomass of phytoplankton was much lower in the AAFW systems. Among the cyanobacteria the dominating genera were Microcystis aeruginosa including some Anabaena flosaquae, while the diatoms were dominated by Achnanthes lanceolata and to a lesser extent by Melosira spp. While Green algae and Cyanobacteria dominated the phytoplankton community in the AAFW systems, the dominating taxa were $M$. aeruginosa and S. obliquus. Though nutrients are important for algal growth and phosphorus is the limiting element in the AAFW system, similar with the Lake Haugatjern [29]. Phytoplankton community was sandwiched by the nutrient loading and the grazing of zooplankton [30]. The mean summer phytoplankton abundance and biomass of Jiyu river was about $5.59 \times 10^{6}$ ind. $\mathrm{l}^{-1}$ and $6.33 \mathrm{mg} \cdot \mathrm{l}^{-1}$ while it decreased to $2.53 \times 10^{5} \mathrm{ind}^{-\mathrm{l}^{-1}}$ and $1.48 \mathrm{mg} \cdot \mathrm{l}^{-1}$ in the effluent of the AAFW systems. The mean summer cyanobacterial biomass of Jiyu river was about $5.36 \mathrm{mg} \cdot \mathrm{l}^{-1}$, while it decreased to $0.18 \mathrm{mg} \cdot \mathrm{l}^{-1}$ in the effluent (Figure 5). The concentrations of $M$. aeruginosa in phytoplankton tank decrease from $8.64 \pm 0.37 \times 10^{4}$ ind. $1^{-1}$ to $1.44 \pm 0.13 \times 10^{4}$ ind. $l^{-1}$, and the concentrations of $S$. obliquus increase from $5.8 \times 10^{3}$ ind. $\mathrm{l}^{-1}$ to $1.2 \pm 0.14 \times 10^{4}$ ind. $\mathrm{l}^{-1}$ (Table 2). The percentage of cyanobacteria in the Jiyu river decrease from $43.93 \%$ to $2.36 \%$ in the phytoplankton tank and the biomass of cyanobacteria decrease from $2.78 \mathrm{mg} \cdot \mathrm{l}^{-1}$ to 0.08 
$\mathrm{mg} \cdot \mathrm{l}^{-1}$. Compared with the Jiyu river and zooplankton chamber, the biomass and percentage of Chlorophytes in the phytoplankton tank is the highest $\left(2.42 \mathrm{mg} \cdot \mathrm{l}^{-1}, 69.60 \%\right)$. The grazing of Daphnia result in the increase of percent of cyanobacteria in effluent from $2.36 \%$ to $10.17 \%$ and the biomass of cyanobacteria increase from $0.08 \mathrm{mg} \cdot \mathrm{l}^{-1}$ to $0.15 \mathrm{mg} \cdot \mathrm{l}^{-1}$ (Figure 6). The dominanted phytoplankton group in Jiyu river, the phytoplankton tank and the effluent were Cyanophta, Chlorophtes and Cryptophtes, respectively. And the most predominant phytoplankton taxa-Microcystis always formed large colonies and floated on the surface of the river water, which were not perhaps easily fed upon by crustacean zooplankton [31].

\subsubsection{The Change of Zooplankton Community}

In the present study, the crustacean zooplankton community in Jiyu river was dominated by omnivorous cladocerans and calanoids, mainly, Diaphanosoma $s p$ and Sinocalanus dorrii. After the operation by AAFW system, the crustacean zooplankton
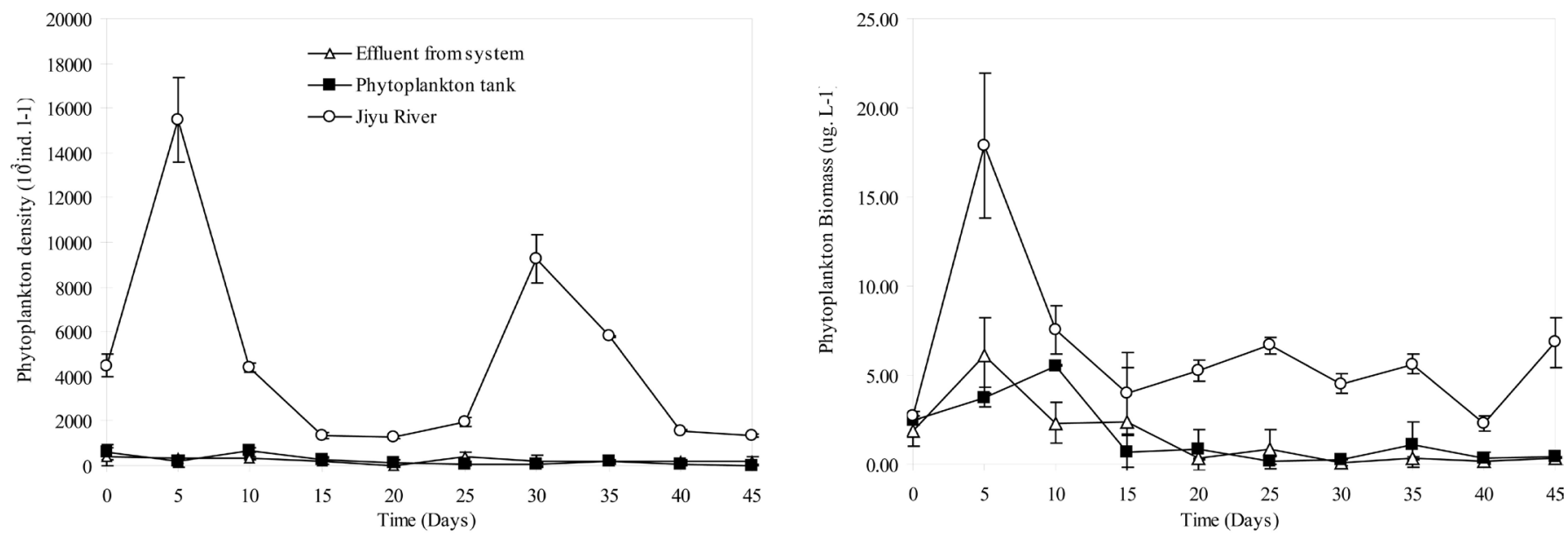

Figure 5. Variations of total phytoplankton abundance (left) and total phytoplankton biomass (right) during operation of the continuous flow AAFW system. Open circle Jiyu River, black square phytoplankton tank and inverted triangle effluent from system.
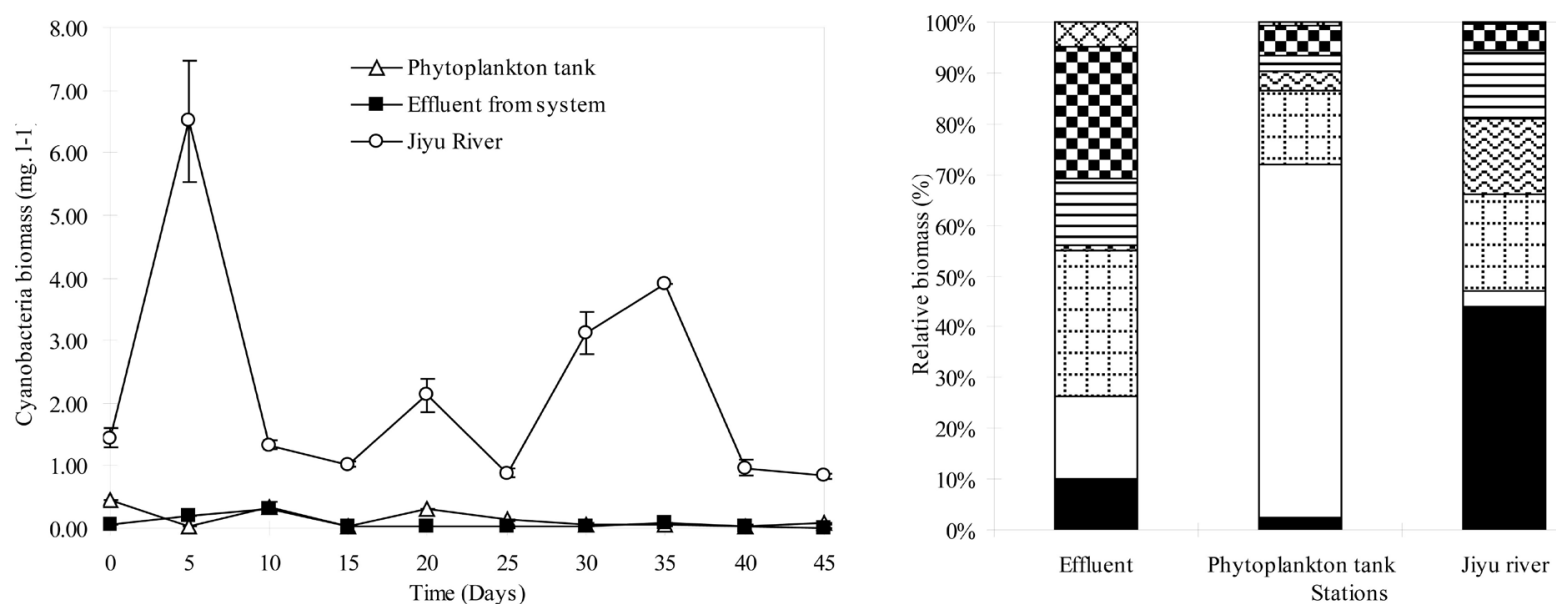

Q Chrysophyta a Pyrrophyta 口Euglenophytes DCryptophytes $\square$ Bacillariophytes $\square$ Chlorophytes

- Cyanobacteria

Figure 6. Variations of total caynobacteria biomass (left) and the relative biomass of phytoplankton taxon (right) at different sites. Open circle Jiyu River, inverted triangle phytoplankton tank, and black square effluent from system. 
Table 2. Abundance (individual $\mathrm{L}^{-1}$ ) of phytoplankton species in the phytoplankton tank.

\begin{tabular}{ccc}
\hline \multirow{2}{*}{ Species name } & \multicolumn{2}{c}{ Abundance(mean \pm SD $)^{\mathrm{a}}$} \\
\cline { 2 - 3 } Cyanobacteria & Day 0 & Day 45 \\
Microcystis aeruginosa & $8.64 \pm 0.37 \times 10^{4}$ & $1.44 \pm 0.13 \times 10^{4}$ \\
Bacillariophyceae & $<1000$ & $\mathrm{ND}$ \\
Melosir granulata & $\mathrm{ND}$ & $<1000$ \\
Achnanthes lanceolata & $\mathrm{ND}$ & $<1000$ \\
Chlorophyceae & $5.8 \pm 0.22 \times 10^{3}$ & $1.2 \pm 0.14 \times 10^{4}$ \\
Scenedesmus obliquus & $\mathrm{ND}$ & $<1000$ \\
S. quadricauda & $\mathrm{ND}$ & $<1000$ \\
Chlorella vulgaris & &
\end{tabular}

${ }^{\mathrm{N} N D}$ not detected in 10-ml sample, $<1000$ detection of one individual in 10-ml sample.

community changed towards large cladocerans, mainly Daphnia pulex and Daphnia cucullata, and Mesocyclops leuckarti in the zooplankton chamber. The average summer abundance and biomass of crustacean zooplankton (May-July. inclusive) increased from 80.53 ind. $\mathrm{l}^{-1}$ and $0.34 \mathrm{mg} \cdot \mathrm{l}^{-1}$ in Jiyu river to 315.23 ind. $\mathrm{l}^{-1}$ and $1.53 \mathrm{mg} \cdot \mathrm{l}^{-1}$ in the zooplankton chamber. Daphnia sp. changed from a summer mean of 7.90 ind. $1^{-1}$ and $0.41 \mathrm{mg} \cdot \mathrm{l}^{-1}$ in Jiyu river to 28.85 ind. $\mathrm{l}^{-1}$ and $0.88 \mathrm{mg} \cdot \mathrm{l}^{-1}$ in the zooplankton chamber. (Figure 7). Bosmina spp. showed a summer mean of 3.50 ind. $1^{-1}$ and $0.25 \mathrm{mg} \cdot \mathrm{l}^{-1}$ in Jiyu river to 17.34 ind. $\mathrm{l}^{-1}$ and $0.49 \mathrm{mg} \cdot \mathrm{l}^{-1}$ in.the zooplankton chamber. The number of cyclopoid copepods increased from 27 ind. $\mathrm{l}^{-1}$ in Jiyu river to 77 ind. $\mathrm{l}^{-1}$ in the zooplankton chamber. Predacious zooplankton was represented by Leptodora kindtii (day-time sampling only) appearing with a summer mean of less than 1 ind. $1^{-1}$ all years. Daphnia $s p$. and Bosmina sp. showed also changes in the percentage in crustacean zooplankton community and the mean body size. The percentage of Daphnia in the crustacean zooplankton community in zooplankton chamber was much higher than Jiyu river (65.62\% to $13.28 \%$ ) (Figure 8 ), and the mean body length of crustacean zooplankton in zooplankton chamber is much higher than those in the Jiyu river $(0.9733 \mathrm{~mm}$ to 0.9180 $\mathrm{mm}$ ). The ratio of zooplankton and phytoplankton in zooplankton chamber is the higher, which may give a heavy grazing pressure on phytoplankton (Figure 9). Elser et al. (1988) found that, under conditions of Daphnia dominance, phytoplankton growth was P-limited while in situations where calanoids dominated, the phytoplankton were N-limited [32]. Daphnia ecology and physiology focused on its functional responses related to food quantity, they also addressed qualitative aspects related to phytoplankton community composition, size, shape and digestibility [16]. Similar patterns were found in the present study, microcystis blooms were less efficient consumed by the omnivorous or small-bodied crustacean zooplankton in warm-water lakes [11] [30]. However, the abundance of $D$. pulex in zooplankton chamber appeared unaffected by the shift of phytoplankton species. This observation may imply that the cyanobacterium species growing in the phytoplankton tank was well grazed by $D$. pulex. 

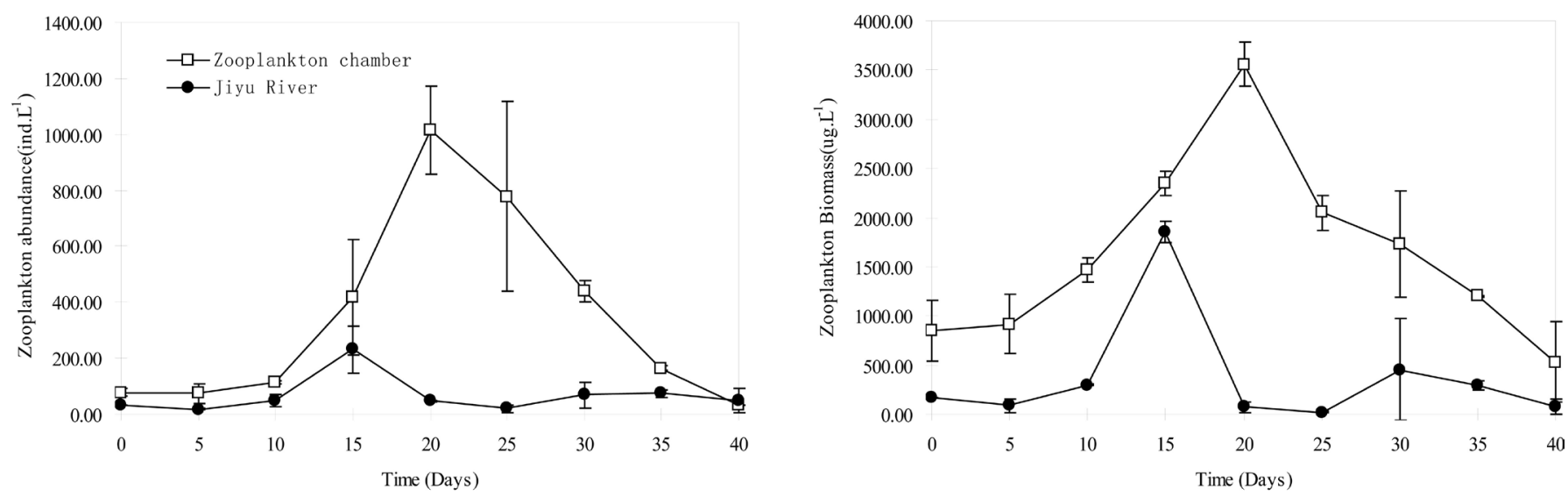

Figure 7. Variations of the abundance (left) and biomass (right) of crustacean zooplankton in the zooplankton chamber and Jiyu river. Black circle Jiyu river, Open square zooplankton chamber.
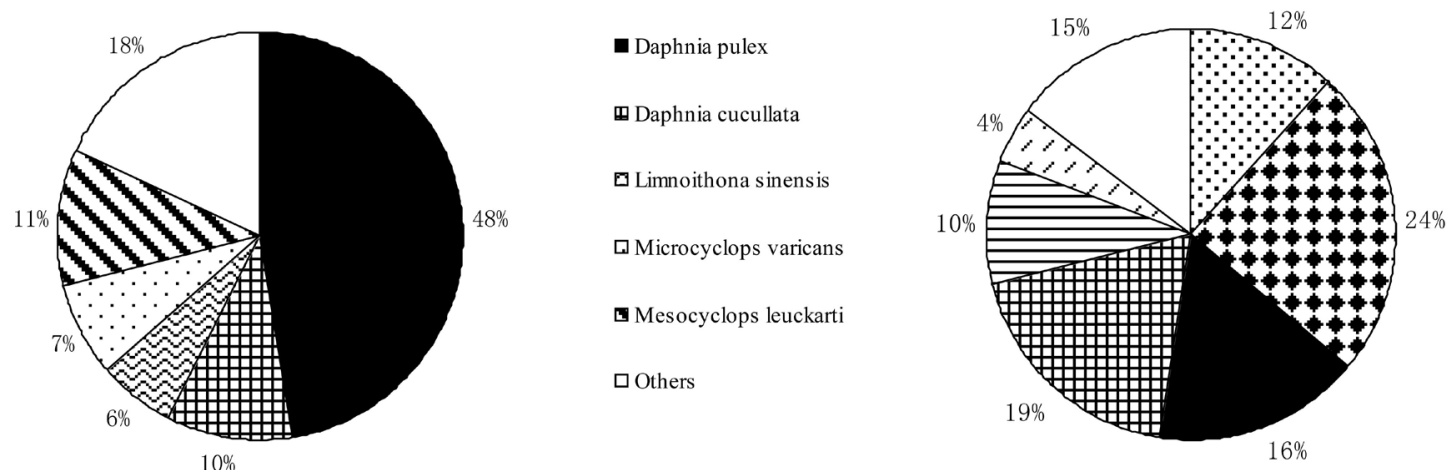

๑Diaphanosoma brachyurum

EDiaphanosoma sarsi

- Daphnia pulex

巴 Daphnia cucullata

$\square$ Sinocalanus dorrii

$\square$ Cyclops vicinus

$\square$ Others

Figure 8. The relative biomass of crustacean zooplankton species in effluent (left) and Jiyu river (right).
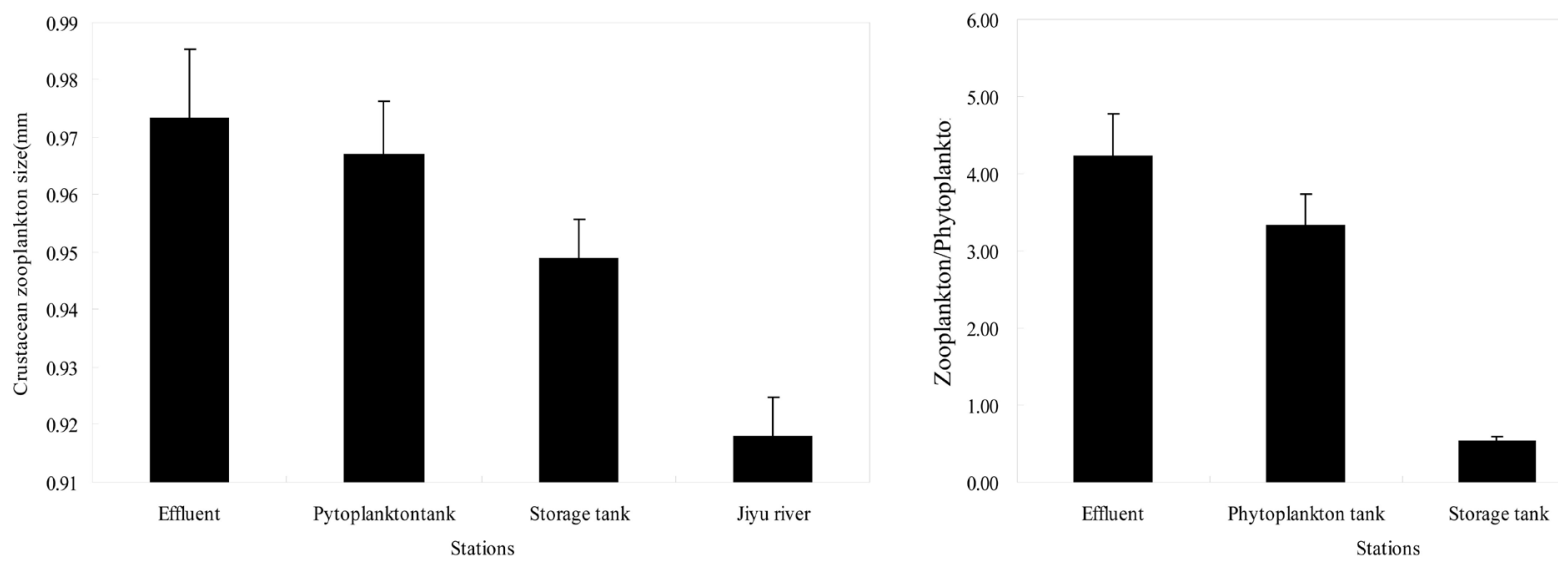

Figure 9. The mean Crustacean zooplankton size (left) and the Zooplankton/Phytoplankton (right) in different sites.

\subsection{The Change of Trophic Cascade in the AAFW Systems}

Most field investigations that have analyzed the effects of nutrient ratios on zooplankton populations have provided evidence for nutrient limitation, particularly of $\mathrm{P}$, in 
natural zooplankton communities [28] [33] [34]. Isotopic analysis has shown a high assimilation efficiency of P in Daphnia grazing on P-deficient food [35]. Relative to copepods, the cellular ratio of N:P in Daphnia is lower, and as a result they are considered to have comparatively high requirements for $\mathrm{P}$ relative to $\mathrm{N}$ in their diets [34] [36]. Many field studies reported that there is a positive relationship between the abundance of Daphnia and seston phosphorus [28] [33]. Phytoplankton biomass decreased during this period and was associated with relatively high Daphnia abundance, suggesting limitation of food [37]. There was, however, no overall shift towards dominance of smaller genera such as Bosmina [30]. The ratio of TN:TP was high in the zooplankton chamber and low in Jiyu river. During the outbreak of Microcystis blooms, the low zooplankton/phytoplankton ratio in the polluted river water may be responsible for the declined selectivity of fish on zooplankton [38]. The low percentage results suggest that the outbreak of Microcystis blooms might be partly grazed by large cladocerans-Daphnia. The mean body length of zooplankton in zooplankton chamber was much higher than the mean body length of zooplankton in Jiyu river. That mainly attribute to the high ratios of Daphnia in the crustacean zooplankton community. A successful control of algal bloom may attribute to the large zooplankton size in eutrophic water.

\subsection{Deployment of the Food Web System}

The material budget of the continuous-flow system was calculated and presented in Figure 10. For 45 days, the total amounts of TN and TP flowing into the system were 120.46 and $6.29 \mathrm{~g}$, respectively, and the amounts flowing out were $85.55 \mathrm{~g}(71.02 \%)$ and $3.31 \mathrm{~g}$ (52.69\%), respectively. Biologically, $29.01 \mathrm{~g}(24.08 \%)$ of TN and $0.04 \mathrm{~g}(0.69 \%)$ of TP were removed by phytoplankton and $3.09 \mathrm{~g}(2.56 \%)$ of TN and $1.78 \mathrm{~g}(28.26 \%)$ of TP by zooplankton. As a high efficiency of nutrients removal ecological engineer, the

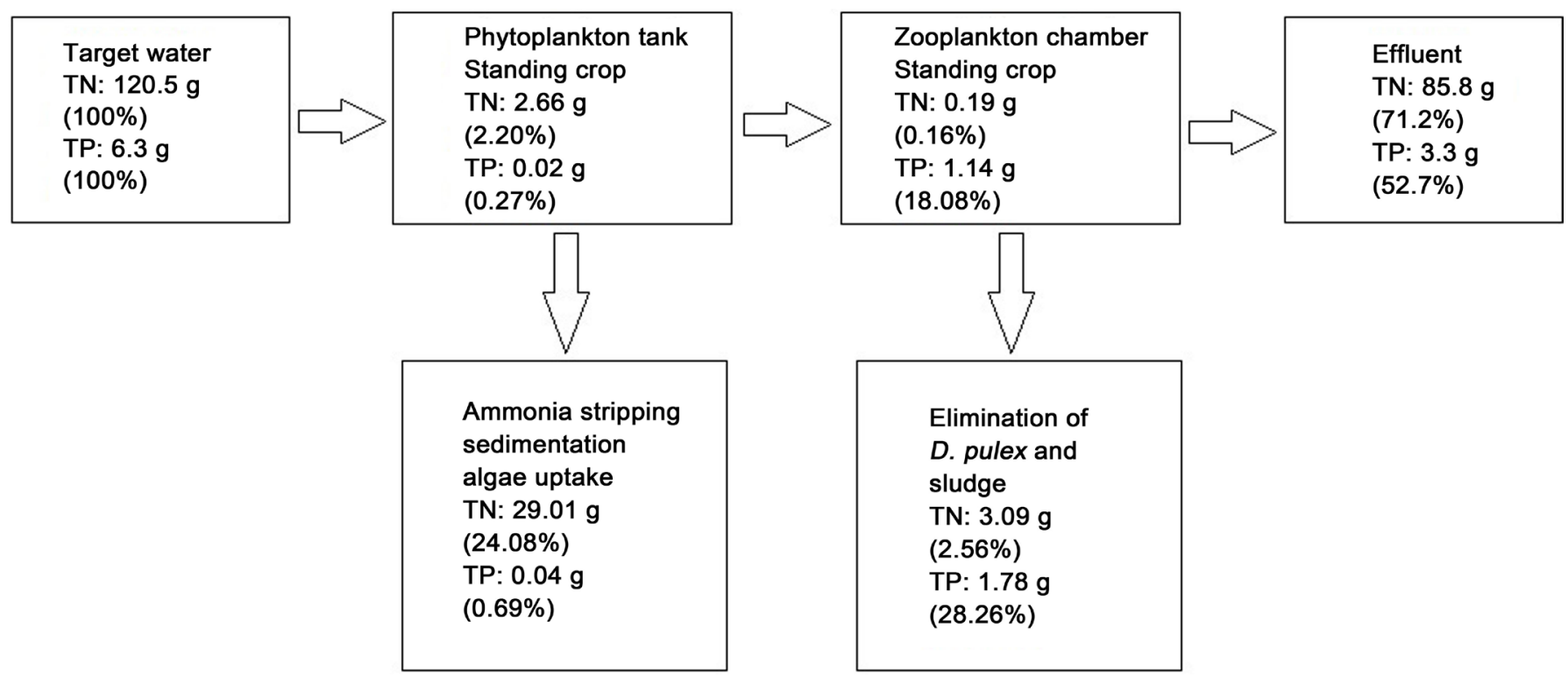

Figure 10. Material budget of nitrogen and phosphorus in the continuous-flow AAFW system. Numbers in parentheses = proportion (\%) to the amounts of nutrients in target stream water. 
construction and operation of AAFW was convenient and low cost. While some occasional contaminations such as toxic chemicals and the limitation of both phytoplankton and zooplankton would result in the collapse of the system. Especially, the development of non-grazeable large algal species such as filamentous and colonial cyanobacteria would increase the risk of system collapse [9] [12]. The present study exhibited that colonial microcystis wouldn't increase the risk of system collapse. The colonial cyanobacteria species- microcystis faced with a high competition with green algae and partly grazed by the larger cladoceran- Daphnia pulex in suitable conditions. These conditions may including with temperate temperature and a low nutrients concentrations. Our studies also exhibited that the ratio of TN: TP play an important role in the control of colonial cyanobacteria bloom. A high abundance of Daphnia in zooplankton community may absorb amounts of $\mathrm{P}$ loading and result in the increase of TN:TP ratios. So Daphnia also had an indirect effect on cyanobacteria other than the direct graze.

\section{Conclusion}

In conclusion, the aquatic food web system can be applied to the management of large volume non-point source pollutions in polluted river waters, which is the resource of the eutrophication and the cyanobacterial bloom in rivers and lakes. The aquatic food web system not only removes the nutrients of sewage efficiently, but also increases the TN:TP ratio significantly by the P-absorbance of Daphnia. The aquatic food web system decreases the percent of harmful cyanobacteria in phytoplankton community and identified the dominance of Daphnia in zooplankton community. That would be more important in the control of cyanobacterial bloom and the ecological safety of the aquatic ecosystems.

\section{Acknowledgements}

This work was supported by the National Natural Science Foundation of China (No. 31300395), the State Key Laboratory of Chinese Academy of Sciences Research Development Fund (No. 2014SKL008), The Doctoral Program of Higher Education Research Fund (No. 20133418120007). We sincerely thank Professor Xiangming Tang for his help with sample collection.

\section{References}

[1] Jiang, C., Fan, X., Cui G. and Zhang Y. (2007) Removal of Agricultural Non-Point Source Pollutants by Ditch Wetlands: Implications for Lake Eutrophication Control. Hydrobiologia, 581, 319-327. http://dx.doi.org/10.1007/s10750-006-0512-6

[2] Braskerud, B.C. (2003) Factors Affecting Nitrogen Retention in Small Constructed Wetlands Treating Agricultural Non-Point Source Pollution. Ecological Engineering, 18, 351370. http://dx.doi.org/10.1016/S0925-8574(01)00099-4

[3] Gao, C., Zhu, J. and Dou Y. (2002) Contribution of Agricultural Non-Point Source Pollution to Water Quality Deterioration in Taihu Lake Watershed: Recent Trends and Research Priorities. Resources and Environment in the Yangtze Basin, 11, 260-263. (In Chinese)

[4] Carpenter, S.R., et al. (1987) Regulation of Lake Primary Productivity by Food Web Structure. 
Ecology, 68, 1868-1876. http://dx.doi.org/10.2307/1939878

[5] Schindler, D. W, Hecky, R.E., Findlay, D.L., et al. (2008) Eutrophication of Lakes Cannot Be Controlled by Reducing Nitrogen Input: Results of a 37-Year Whole-Ecosystem Experiment. Proceedings of the National Academy of Sciences of the United States of America, 105, 11254-11258. http://dx.doi.org/10.1073/pnas.0805108105

[6] Shang, G.P. and Shang, J.C. (2007) Spatial and Temporal Variations of Eutrophication in Western Chaohu Lake, China. Environmental Monitoring and Assessment, 130, 99-109. http://dx.doi.org/10.1007/s10661-006-9381-8

[7] Deng, D.G., Xie, P., Zhou, Q., Yang, H., Guo, LG. and Geng, H. (2008) Field and Experimental Studies on the Combined Impacts of Cyanobacterial Blooms and Small Algae on Crustacean Zooplankton in a Large, Eutrophic, Subtropical, Chinese Lake. Limnology, 9, 1-11. http://dx.doi.org/10.1007/s10201-007-0229-X

[8] Kawasaki, L.Y., Tarifeno-Silva, E., Yu, D.P., Gordon, M.S. and Chapman, D.J. (1982) Aquacultural Approaches to Recycling of Dissolved Nutrients in Secondarily Treated Domestic Wastewaters-I Nutrient Uptake and Release by Artificial Food Chains. Water Research, 16, 37-49. http://dx.doi.org/10.1016/0043-1354(82)90051-3

[9] Jung, D., Cho, A., Zo, Y.G., Choi, S.I. and Ahn, T.S. (2009) Nutrient Removal from Polluted Stream Water by Artificial Aquatic Food Web System. Hydrobiologia, 630, 149-159. http://dx.doi.org/10.1007/s10750-009-9788-7

[10] Rim, C.S., Shin, J.K. and Cho, K.J. (2000) The Trend and Assessment of Water Pollution for Midstream to Downstream of the Kum River. Journal of the Korean Society for Limnology, 33, 51-60.

[11] Benndorf, J., Böing, W., Koop, J. and Neubauer, I. (2002) Top-Down Control of Phytoplankton: The Role of Time Scale, Lake Depth and Trophic State. Freshwater Biology, 47, 2282-2295. http://dx.doi.org/10.1046/j.1365-2427.2002.00989.x

[12] Kim, S.R., Woo, S.S., Cheong, E.H. and Ahn, T.S. (2003) Nutrient Removal from Sewage by an Artificial Food Websystem Composed of Phytoplankton and Daphnia magna. Ecological Engineering, 21, 249-258. http://dx.doi.org/10.1016/j.ecoleng.2003.11.003

[13] Work, K.A. and Havens, K.E. (2003) Zooplankton Grazing on Bacteria and Cyanobacteria in a Eutrophic Lake. Journal of Plankton Research, 25, 1301-1306.

http://dx.doi.org/10.1093/plankt/fbg092

[14] Cichra, M.F., Badylak, S., Henderson, N., Rueter, B.H. and Phlips, E.J. (1995) Phytoplankton Community Structure in the Open Water Zone of a Shallow Subtropical Lake (Lake Okeechobee, Florida, USA). Archiv fur Hydrobiologie (Special Issue Advances in Limnology), 45, 157-175.

[15] Rondel, C., Arfi, R., Corbin, D., et al. (2008) A Cyanobacterial Bloom Prevents Fish Trophic Cascades. Freshwater Biology, 53, 637-651. http://dx.doi.org/10.1111/j.1365-2427.2007.01894.x

[16] Hessen, D.O. (2008) Efficiency, Energy and Stoichiometry in Pelagic Food Webs. Reciprocal Roles of Food Quality and Food Quantity. Freshwater Reviews, 1, 43-57. http://dx.doi.org/10.1608/FRJ-1.1.3

[17] Tanner, C.C. (2001) Growth and Nutrient Dynamics of Soft-Stem Bulrush in Constructed Wetlands Treating Nutrient-Rich Wastewaters. Wetlands Ecology and Management, 9, 4973. http://dx.doi.org/10.1023/A:1008454901954

[18] Havens, K.E., East, T.L. and Beaver, J.R. (1996) Experimental Studies of ZooplanktonPhytoplankton-Nutrient Interactions in a Large Subtropical Lake (Lake Okeechobee, Florida, USA). Freshwater Biology, 36, 579-597. 
http://dx.doi.org/10.1046/j.1365-2427.1996.00122.x

[19] Voltolina, D., Cordero, B., Nieves, M. and Soto, L.P. (1998) Growth of Scenedesmus sp. in Artificial Wastewater. Bioresource Technology, 68, 265-268.

http://dx.doi.org/10.1016/S0960-8524(98)00150-3

[20] Somodi, I. and Botta-Dukat, Z. (2004) Determinants of Floating Island Vegetation and Succession in a Recently Flooded Shallow Lake, Kis-Balaton (Hungary). Aquatic Botany, 79, 357-366. http://dx.doi.org/10.1016/j.aquabot.2004.03.002

[21] Azza, N., Denny, P., Koppel, J.V.D. and Kansiime, F. (2006) Floating Mats: Their Occurrence and Influence on Shoreline Distribution of Emergent Vegetation. Freshwater Biology, 51, 1286-1297. http://dx.doi.org/10.1111/j.1365-2427.2006.01565.x

[22] APHA (2001) Standard Methods for the Examination of Water and Wastewater. 20th Edition, American Public Health Association, Washington DC.

[23] Hu, H.J., Li, R., Wei, Y.X., Zhu, C., Chen, J. and Shi, Z.X. (1979) Freshwater Algae in China. Science Press, Shanghai. (In Chinese)

[24] Zhang, Z.S. and Huang, X.F. (1991) Research Methods of Freshwater Plankton. Science Publishers, Beijing.

[25] Han, J.Y. and Huh, M. (1999) Removal of Nitrogen and Phosphorus in Sewage by Change of Operating Conditions on SRP (Sequencing Batch Reactor) Process. Journal of the Korean Society for Water Pollution Research Control, 15, 241-255.

[26] Tam, N.F.Y. and Wong, Y.S. (1989) Wastewater Nutrient Removal by Chlorella pyrenoidosa and Scenedesmus sp. Environmental Pollution, 58, 19-34.

http://dx.doi.org/10.1016/0269-7491(89)90234-0

[27] Wang, X.L., Peng, Y.Z., Wang, S.Y., Fan, J. and Cao, X.M. (2006) Influence of Wastewater Composition on Nitrogen and Phosphorus Removal and Process Control in $\mathrm{A}^{2} \mathrm{O}$ Process.

Bioprocess and Biosystems Engineering, 28, 397-404.

http://dx.doi.org/10.1007/s00449-006-0044-5

[28] Brett, M.T., Müller-Navarra, D.C. and Park, S.K. (2000) Empirical Analysis of the Effect of Phosphorus Limitation on Algal Food Quality for Freshwater Zooplankton. Limnology and Oceanography, 45, 1564-1575. http://dx.doi.org/10.4319/lo.2000.45.7.1564

[29] Reinertsen, H., Jensen, A., Koksvik, J.I., Langel, A. and Olsen, Y. (1989) Effect of Fish Removal from a Eutrophic, Limnetic Ecosystem. Canadian Journal of Fisheries and Aquatic Sciences, 47, 166-173. http://dx.doi.org/10.1139/f90-018

[30] Iwabuchi, T. and Urabe, J. (2010) Phosphorus Acquisition and Competitive Abilities of Two Herbivorous Zooplankton, Daphnia pulex and Ceriodaphnia quadrangular. Ecological Research, 25, 619-627. http://dx.doi.org/10.1007/s11284-010-0692-4

[31] Persson, J., Brett, M.T., Vrede, T. and Ravet, J.L. (2007) Food Quantity and Quality Regulation of Trophic Transfer between Primary Producers and a Keystone Grazer Daphnia in Pelagic Freshwater Food Webs. Oikos, 116, 1152-1163. http://dx.doi.org/10.1111/j.0030-1299.2007.15639.x

[32] Elser, J.J., Elser, M.M., MacKay, N.A. and Carpenter, S.R. (1988) Zooplankton-Mediated Transitions between N- and P-Limited Algal Growth. Limnology and Oceanography, 33, 1-14. http://dx.doi.org/10.4319/lo.1988.33.1.0001

[33] Hassett, R.P., Cardinale, B., Stabler, L.B. and Elser, J.J. (1997) Ecological Stoichiometry of N and $\mathrm{P}$ in Pelagic Ecosystems: Comparison of Lakes and Oceans and Emphasis on the Zooplankton-Phytoplankton Interaction. Limnology and Oceanography, 42, 648-662.

http://dx.doi.org/10.4319/lo.1997.42.4.0648 
[34] McCarthy, V., Donohue, I. and Irvine, K. (2006) Field Evidence for Stoichiometry Relationships between Zooplankton and $\mathrm{N}$ and $\mathrm{P}$ Availability in a Shallow Calcareous Lake. Freshwater Biology, 51, 1589-1604. http://dx.doi.org/10.1111/j.1365-2427.2006.01599.x

[35] DeMott, W.R., Gulati, R.D. and Siewertsen, K. (1998) Effects of Phosphorus-Deficient Diets on the Carbon and Phosphorus Balance of Daphnia magna. Limnology and Oceanography, 43, 1147-1161. http://dx.doi.org/10.4319/lo.1998.43.6.1147

[36] Bukovinszky, T., Verschoor, A.M., Helmsing, N.R., Bezemer, T.M., Bakker, E.S., Vos, M. and Domis, L.N.D. (2012) The Good, the Bad and the Plenty: Interactive Effects of Food Quality and Quantity on the Growth of Different Daphnia Species. PLoS ONE, 7, e42966. http://dx.doi.org/10.1371/journal.pone.0042966

[37] Wojtal-Frankiewicz, A. and Frankiewicz, P. (2011) The Impact of Pelagic (Daphnia longispina) and Benthic (Dreissena polymorpha) Filter Feeders on Chlorophyll and Nutrient Concentration. Limnologica, 41, 191-200. http://dx.doi.org/10.1016/j.limno.2010.09.001

[38] Filstrup, C.T., Hillebr, H., Heathcote, A.J., et al. (2014) Cyanobacteria Dominance Influences Resource Use Efficiency and Community Turnover in Phytoplankton and Zooplankton Communities. Ecology Letters, 17, 464-474. http://dx.doi.org/10.1111/ele.12246

\section{Submit or recommend next manuscript to SCIRP and we will provide best service} for you:

Accepting pre-submission inquiries through Email, Facebook, LinkedIn, Twitter, etc.

A wide selection of journals (inclusive of 9 subjects, more than 200 journals)

Providing 24-hour high-quality service

User-friendly online submission system

Fair and swift peer-review system

Efficient typesetting and proofreading procedure

Display of the result of downloads and visits, as well as the number of cited articles

Maximum dissemination of your research work

Submit your manuscript at: http://papersubmission.scirp.org/

Or contact oje@scirp.org 